\title{
Громада як суб’єкт культури локальної демократії
}

\author{
Цумарєв М. І., Центральноукраїнський інституту Приватного акціонерного товариства «Вищий \\ навчальний заклад «Міжрегіональна Академія управління персоналом»
}

Аналізуються особливості територіальної громади як суб’єкта культури локальної демократії - специфічної сфери локальної політичної культури, що стосується знань, умінь, навичок застосування законодавчо визначених механізмів локальної демократії, політичної участі у згаданих механізмах.

У ході дослідження проаналізовано основні підходи до розуміння територіальної громади, їі правовий статус та специфіку територіальної громади як групового суб'єкта культури локальної демократії. Виявлено особливості культури локальної демократії, притаманні різним рівням групових суб'єктів (базовий, основний, загальний), які виокремлені нами за критеріями: кількості населення територіальної громади; міцності соціальних зв'язків мешканців, усвідомлення ними необхідності участі у вирішенні спільних проблем.

3'ясовано, що до групових суб'єктів культури локальної демократії належать територіальні громади (мешканці населених пунктів в межах таких адміністративно-територіальних одиниць, як місто, селище, село); частини територіальної громади на мікрорівні, локалізовані за територіальною ознакою (мешканці району у населеному пункті, мікрорайону, кварталу, вулиці, багатоквартирного будинку). Також шляхом аналізу нормативних актів встановлено, що суб'єктом механізмів локальної демократії може бути територіальна громада в цілому, але окремі механізми можуть бути здійснені тільки на рівні частини територіальної громади.

Ключові слова: самоорганізація; громада; механізми локальної демократії; культура локальної демократії

\section{Community as a subject of local democracy culture}

\section{Tsumarev M. I., Central-Ukrainian Institute of Private Joint-Stock Company «Higher Educational Institution» Interregional Academy of Personnel Management»}

The peculiarities of the territorial community as a subject of the local democracy culture- a specific sphere (part) of local political culture, system of knowledge, skills, values, the convictions of the members of the territorial community regarding the legislatively determined mechanisms of local democracy (public hearings, citizens' meetings at the residenceplace, activities of self-organization bodies of the population, local referendums), and also includes forms of political participation of the community in the mechanisms, behavior examples, social norms, fundamental principles and civic Institutions that target subjects on one or other forms of activity in politics, provide a transfer of accumulated experience, assist local democracy strength in time.

During research the main approaches to the understanding of the local community, its legal status and the specific local community group as the subject of culture of local democracy are analyzed. The cultural features of local democracy, characterized by different levels of group subjects (basic, main, general), are distinguished by us according to the criteria: the population of the territorial community; the strength of social relationships between the residents, their awareness of the necessity for participation in solving common problems.

It has been discovered that the local democracyculture, which primarily reflects the level of awareness of the citizen's public tasks and their practical activity in their implementation, can be maximum effectively implemented by the community as a group entity. In this sense, it is a structural element of civil life and the manifestation of the degree of societymaturity, the ability to ensure general civil interests, forms and mechanisms for the development and implementation of common decisions, coordinated actions.

It was found out that territorial communities (residents of such administrative-territorial units as city, village, urban-typesettlement) belong to the group of subjects of the local democracy culture; parts of the territorial community at the micro level localized according to the territorial characteristics (residents of the district in the settlement, micro district, urban block, street, multistoried building). Also, by analyzing the normative acts, it is established that the subject of mechanisms of local democracy may be the territorial community as a whole, but certain mechanisms can be implemented only at the level of the territorial community part.

It was found out that local communities (at the territorial communitylevel or a part of it), united by common goals, tasks and interests, are capable promptly and effectively to solve local issues on the basis of local selfgovernment and self-organization.

Keywords: self-organization; community; local democracy mechanisms; local democracy culture 


\section{Община как субъект культури локальной демократии}

\section{Цумарев М. И., Центральноукраинский института Частного акционерного общества «Высшее учебное заведение «Межрегиональная Академия управления персоналом»}

Анализируются особенности территориальной общины как субъекта культуры локальной демократии - специфической сферы локальной политической культуры, касающейся знаний, умений, навыков применения законодательно определенных механизмов локальной демократии, политического участия в упомянутых механизмах.

В ходе исследования проанализированы основные подходы к пониманию территориальной общины, ее правовой статус и специфику территориальной общины как группового субъекта культуры локальной демократии. Выявлены особенности культуры локальной демократии, присущие различным уровням групповых субъектов (базовый, основной, общий), которые выделены нами по критериям: количеству населения территориальной общины; прочности социальных связей жителей, осознание ими необходимости участия в решении общих проблем.

Установлено, что к групповым субъектам культуры локальной демократии относятся территориальные общины (жители населенных пунктов в пределах таких административно-территориальных единиц, как город, поселок, село) части территориальной общины на микроуровне, локализованные по территориальному признаку (жители района в населенном пункте, микрорайона, квартала, улицы, многоквартирного дома). Также путем анализа нормативных актов установлено, что субъектом механизмов локальной демократии может быть территориальная община в целом, но отдельные механизмы могут быть осуществлены только на уровне территориальной общины.

Ключевые слова: самоорганизация; община; механизмы локальной демократии; культура локальной демократии

\section{Постановка проблеми.}

$\mathrm{A}$ ктуальність дослідження обумовлюється, по-перше, недостатньою вивченістю у політичній науці культури локальної демократії, по-друге, тією критичною масою нерозв'язаних проблем, що перешкоджає становленню громадянського суспільства в Україні, яка накопичилась саме на рівні місцевих громад (локальних спільнот).

Тим часом саме місцеві громади (локальні спільноти), об'єднані спільними цілями, завданнями та інтересами, здатні на засадах місцевого самоврядування та самоорганізації оперативніше i результативніше домагатися вирішення питань місцевого значення, що стосуються найважливіших проблем життєзабезпечення громадян.

\section{Аналіз досліджень і публікацій.}

Термін «територіальна громада» може використовуватись у різних значеннях. Традиційне розуміння громади -це сукупність місцевих жителів, які постійно проживають у межах адміністративно-територіальної одиниці. Впродовж століть в Україні громада була основною територіальною одиницею. Вона користувалася правом самоврядування, формувала свої органи управління, була власником частини землі, розподіл якої здійснювався за рішенням зборів громади. Громада несла кругову поруку перед державою за сплату податків; схід громади накладав податки на членів громади.

Дослідники самоорганізації громадян на місцевому (локальному) рівні, (Брудний В., Була С., Ващук-Огданська О., Крупник А., Лациба М., Лендьєл М., Лукеря I., Орзіх М., Орловський О., Панченко Т., Слиз А., Щепанський М. та ін.) використовують такі терміни як «місцева», «сусідська», «локальна» (від латин. «місце») спільнота. У англомовних виданнях вживається термін «community» (англ. «спільнота»). При цьому поняття «спільнота» в українській мові, так само як і поняття «community» в англійській, багатозначне і може означати: «громада», «місцеве співтовариство», «населення», «місцевий населений пункт», «територія проживання громади»; «спільнота за інтересами»; «партнерство»; «володіння загальними правами»; «суспільство», «громадськість», «народ», «громадяни»; «збалансоване співтовариство організмів» [19]. У сучасній науковій літературі терміном «спільнота» також позначають соціальну групу, яка має певне спільне середовище проживання і певні спільні інтереси. Відомий фахівець у галузі місцевих і сусідських спільнот, експерт ЮНЕСКО Г. Андоніан висловив припущення, що «термін community походить від терміну «communication» - комунікація, взаємодія, бо саме цей процес і створює спільноту» [9, с. 268].

Територіальна громада, за визначенням М. Баймуратова, - це «сукупність фізичних осіб, які постійно мешкають на певній території та пов'язані територіально особистісними зв'язками системного характеру» [4, с. 115]. Значно докладніше визначення територіальної громади дає О. Батанов, акцентуючи на процесі реалізації спільнотою власних інтересів [5, с. 77]. Автори колективної монографії «Місцеве самоврядування в Україні: проблеми та перспективи» розглядають територіальну громаду як спільність жителів, «об'єднаних шляхом природного розселення і постійним проживанням в межах одного або кількох населених пунктів 3 єдиним адміністративним центром» $[12$, с. 37]. М. Орзіх зазначає, що члени територіальної громади не обов'язково повинні постійно проживати на певній території, тим паче, мати певне громадянство. Важливо, щоб вони на цій території володіли нерухомим майном або були платниками податків [14, с. 67]. 
Як сукупність громадян України, котрі спільно проживають у міському чи сільському поселенні, мають колективні інтереси і визначений законом правовий статус, термін «територіальна громада» закріплений Конституцією України 1996 року (ст. 142, 143). При цьому територіальна громада розуміється як первинний суб'єкт місцевого самоврядування (здійснює його як безпосередньо, так і через органи місцевого самоврядування). Тобто місцеве самоврядування є виявом самоорганізації громадян на найнижчому рівні публічного управління, яким в Україні є територіальна громада [1].

Закон України «Про місцеве самоврядування в Україні» деталізує визначення територіальної громади як певної самоорганізації громадян, об'єднаних за територіальною ознакою 3 метою задоволення в межах законодавства своїх колективних потреб і захисту своїх законних прав та інтересів [2].

У Свропейській хартії місцевого самоврядування територіальна громада виступає публічним власником, об'єднанням всіх громадян адміністративно-територіальної одиниці (села, селища, міста, району в місті), які можуть простою більшістю від свого складу на основі загальних зборів відповідно до конституції вирішувати питання щодо своєї спільної, неподільної публічної власності. Тобто - це територіальна громада, яка набула статусу юридичної особи публічного права $[8$, c. 253].

Підсумовуючи різні підходи до трактування територіальної громади, можна виокремити іiі основні ознаки:

1) спільне проживання осіб (жителів) на певній території;

2) об'єднання всіх жителів, які мешкають на певній території, незалежно від того, чи $є$ вони громадянами даної держави, тобто членами територіальної громади можуть бути громадяни даної держави, а також іноземні громадяни, особи без громадянства, котрі постійно мешкають на певній території;

3) спільні інтереси жителів, які мають специфічний характер і виявляються у вигляді широкого спектра системних індивідуально-територіальних зв'язків;

4) спільна комунальна власність (територіальна громада є суб'єктом права комунальної власності);

5) сплачування комунальних податків (члени територіальної громади є платниками місцевих податків і зборів) [13, с. 59].

Завдання нашого дослідження зумовлюють особливу увагу до локально-політичних аспектів життедіяльності територіальної громади. Тому особливо продуктивним вважаємо теоретико-ме- тодологічний підхід до дослідження політичних явищ та процесів на локальному рівні, запропонований українською дослідницею Мирославою Лендьєл. Авторка вважає за необхідне враховувати не лише такі інституційно-правові чинники, як система організації публічної влади та виборів до ііі органів, загальнонаціональні політичні характеристики, а й характеристики місцевого політичного простору: розташування щодо центру; поєднання природних умов та вторинних соціально-економічних характеристик; історичний досвід, історія державної належності; політична структуризація суспільства; культурологічні характеристики, зокрема менталітет; якість політичної еліти; стан громадянського суспільства та політичної культури й соціального капіталу) [10].

Таким чином, аналіз досліджень дає можливість виокремити такі характеристики громади, як суб' єкта культури локальної демократії: рівень демократичності спільноти та рівень ефективності використання нею механізмів локальної демократії - громадських слухань, зборів громадян за місцем проживання, діяльності органів самоорганізації населення, місцевих референдумів тощо. Ці характеристики залежать від того, наскільки поширена політична участь членів спільноти у всіх іiі формах; наскільки вона репрезентує різні сегменти спільноти, а також наскільки вона обмежена ментальними, соціально-економічними та іншими чинниками; традиції і культура спільноти підтримують основні демократичні принципи; наскільки спільнота довіряє здатності політичної системи розв'язувати проблеми суспільства і своїй спроможності впливати на цей процес (Див.: [6, с. $46-48$, с. $62 ; 10$, с. 15$])$.

Мета дослідження - проаналізувати особливості територіальної громади як суб'єкта культури локальної демократії - специфічної сфери локальної політичної культури, що стосується знань, умінь, навичок використання законодавчо визначених механізмів локальної демократії, політичної участі у згаданих механізмах.

\section{Виклад основного матеріалу.}

Культура локальної демократії, як частина локальної політичної культури, базується на територіальній, насамперед локальній, ідентичності - ідентифікації людини з локальним або місцевим співтовариством, відчуттям причетності до подій, що відбуваються на території безпосереднього мешкання (міста, району, селища, села, мікрорайону). Вона виявляється у формуванні певної системи цінностей і норм поведінки жителів територіï.

Знання, цінності, переконання членів окремих територіальних громад, як щодо політики в цілому, так і щодо політики місцевого (локального рівня), та особливості участі даних територіаль- 
них громад у політичних процесах на зазначених рівнях відображає поняття «локальна політична культура». Специфіка культури локальної демократії, як частини локальної політичної культури, розкривається через осмислення поняття «локальна демократія» та визначення іiі механізмів, оскільки саме система знань, цінностей, переконань членів територіальної громади щодо зазначених механізмів та політична участь у них, на нашу думку, виражає сутність культури локальної демократії.

У дослідженні С. Були локальна демократія трактується як рівень демократії, де головним актором є громада. Цей рівень має особливий інституційний порядок організації влади, що містить елементи самоорганізації, безпосередньої участі громадян у публічному житті. «Основними концептуальними характеристиками локальної демократії є: організація життя територіальної громади на принципах рівності, участі, публічного діалогу; залучення громадян до ведення справ громади, поширення практик місцевих ініціатив, референдумів; самоорганізація населення» [7, с. 37]. I якщо дослідниця стверджує, що «головний чинник, від якого залежать особливості національних моделей демократії, - це рівень громади, який є своєрідним переходом «людина - суспільство» [7, с. 37], то це цілком зрозуміло з позицій системно-структурного підходу, коли виокремлюються рівні «загальне - особливе - одиничне» (Див.: [16, с. 78]. На перших двох рівнях демократії (рівень індивіда і рівень громади), вважає С. Була, визначається внутрішня логіка іiі існування, функціональна необхідність демократії для максимальної реалізації особистості. Коли вдало поєднано обидва рівні, тобто сформульовано таку систему взаємин людини і влади, яка кожному давала б змогу реалізуватися, відображати дійсність через самого себе.

С. Була визначає локальну демократію як один зі способів організації місцевого самоврядування, коли територіальна громада наділена автономією для задоволення своїх інтересів, опираючись на демократичні цінності, використовує демократичні механізми, долучається до процесу ухвалення рішень, поширює інструменти прямої демократії. Поширення практики локальної демократії, зазначає дослідниця, можна назвати тихою демократичною революцією, що забезпечує принцип субсидіарності й роззосередження влади, вимагає легітимізувати владу [7, с. 28].

Отже, впровадження локальної демократії, насамперед, базується на нормативно забезпеченій на загальнодержавному та локальному рівнях спроможності територіальної громади брати активну участь у вирішенні питань місцевого значення. Таким чином, до згаданих С. Булою «де- мократичних механізмів» та «інструментів прямої демократії» слід віднести законодавчо визначені механізми прямої демократії, здійснення яких відбувається в межах територіальної громади. Так, базуючись на аналізі нормативно-правових документів, що регулюють механізми участі членів територіальної громади у вирішенні питань місцевого значення, автори дослідження «Місцева демократія в Україні: нові стандарти» віднесли до зазначених механізмів: громадські слухання; загальні збори громадян за місцем проживання; місцеві ініціативи; консультації з громадськістю; органи самоорганізації населення $[11$, с. 7-8]. У рамках дослідження стану локальної демократії в містах України, В. Брудний, А. Крупник, О. Орловський на основі аналізу положень Конституції та Законів України дійшли висновку, що до механізмів локальної демократії належать: створення і діяльність об'єднань громадян та органів самоорганізації населення, місцеві ініціативи, загальні збори, місцеві референдуми, громадські слухання, громадський контроль [18, с. 5]. На нашу думку, до основних механізмів локальної демократії, які найбільш широко розкривають можливості громади щодо вирішення місцевих питань, слід віднести: громадські слухання, збори громадян за місцем проживання, діяльність органів самоорганізації населення та місцеві референдуми.

Аналізуючи територіальну громаду як колективного суб' єкта локальної демократії, слід зазначити що спільноти міста, району, селища, села, мікрорайону мають, умовно кажучи, різні атрибути локальності $[15$, с. 75], які базуються на визначених Т. Панченком ознаках категорії «локальне співтовариство»:

1) Відносини, що виникають між членами локальної спільноти, мають характер безпосередніх контактів, які базуються на єдності цілей і засобів, що слідує зі спільності повсякденного життя. Отже, організація безпосередніх відносин між людьми й підтримка контактів між ними, властиві для локальної спільноти, зумовлює обмежену кількість їі членів. Вважається, що в ідеалі локальна спільнота нараховує не більше 5000 жителів. Не випадково, що у різноманітних концепціях адміністративно-територіального поділу саме ця кількість населення вважається оптимальною для адміністративно-територіальної одиниці базового рівня.

2) Локальна спільнота відчуває потребу у певних соціальних інститутах, 3 якими пов'язане життя кожної людини. Зазначимо, що лише співтовариства окремих сіл, селищ, малих міст відповідають цим ознакам локальних співтовариств. На урбанізованих територіях локальні спільноти витісняються територіальними спільнотами 
(community) [17, с. 4], для яких властиві менш стійкі зв'язки між членами, нижчий рівень індивідуальної та колективної ідентифікації, готовність до міграції, менш тісні відносин з родиною, а також слабке відчуття спільного господарювання. За великим рахунком ідентифікацію мешканця великого міста з відповідним містом лише 3 певною умовністю можна назвати локальною, вона ближче до регіональної.

3) В умовах сучасної територіальної організації суспільного життя локальні спільноти співіснують 3 іншими територіальними. Не випадково для виокремлення спільнот на місцевому рівні використовують категорії «територіальний публічний колектив», «територіальний колектив громадян», «територіальна громада», для яких показник чисельності населення стає другорядним. Хоча кожна 3 цих категорій характеризується різними підходами та кваліфікуючими ознаками, їх об'єднує право членів на реалізацію публічної влади безпосередньо або через обраних представників, що реалізується через систему місцевого самоврядування. Відповідно, головним критерієм для виокремлення територіальної громади (територіального колективу тощо) $\epsilon$ не чисельність населення, а наближеність влади та суспільних послуг до населення (за цієї логікою як одне село, так і мегаполіс є територіальною громадою).

Але, виходячи зі змісту норм законодавства, що унормовують механізми локальної демократії, можна стверджувати про наявність різних рівнів локалізації територій всередині територіальної громади, мешканці яких можуть реалізувати право на самоорганізацію, використовуючи окремі механізми локальної демократії. Так, до зазначених Т. Панченко територій безпосереднього мешкання, громада яких може виступати суб'єктом локальної демократії (місто, район, селище, село, мікрорайон) [15, с. 75], можна додати наступні: квартал, вулиця, багатоквартирний будинок.

На підтвердження цього можна навести низку положень нормативних актів, виходячи зі змісту яких можна зробити висновок, що суб'єктом окремих механізмів локальної демократії виступає територіальна громада в цілому, але окремі механізми можуть бути здійснені тільки на рівні частини територіальної громади. Зокрема, суб'єктом таких механізмів локальної демократії, як, наприклад, громадські слухання та місцеві ініціативи, $є$ територіальна громада в цілому (тобто всі мешканці адміністративно-територіальної одиниці - міста, села, селища), а для ініціювання громадою даних механізмів необхідно зібрати підписи, кількість яких визначається у відсотках від кількості членів територіальної громади (або встановлюється у вигляді сталої кількості), що затверджується статутом відповідної територіальної громади.
Натомість Закон України «Про органи самоорганізації населення» визначає чітку локалізацію територій, в межах яких можуть створюватися та діяти органи самоорганізації населення:

- територія сільського, селищного комітету - в межах території села, селища;

- вуличного, квартального комітету - в межах території кварталу, кількох, однієї або частини вулиці з прилеглими провулками в місцях індивідуальної забудови;

комітету мікрорайону - в межах території окремого мікрорайону, житлово-експлуатаційної організації в містах;

будинкового комітету - в межах будинку (кількох будинків); комітету району в місті - в межах одного або кількох районів у місті [3].

Отже, стосовно участі у створенні та діяльності органів самоорганізації населення суб'єктом локальної демократії виступає не територіальна громада, а виключно іiї частини, громадяни яких об'єднані спільною територією проживання.

Суб'єктом такого механізму локальної демократії, як загальні збори громадян за місцем проживання може бути як територіальна громада в цілому (за умови відносно невеликої кількості мешканців), так і її частина на мікрорівні (починаючи від багатоквартирного будинку, частини вулиці чи кварталу в районі індивідуальної забудови, тощо).

Спираючись на таке розуміння, можна зробити висновок, що до групових суб'єктів культури локальної демократії належать територіальні громади (мешканці населених пунктів в межах таких адміністративно-територіальних одиниць як місто, селище, село); частини територіальної громади на мікрорівні, локалізовані за територіальною ознакою (мешканці району у населеному пункті, мікрорайону, кварталу, вулиці, багатоквартирного будинку), а на індивідуальному рівні - громадяни як члени територіальної громади.

Базуючись на даному розподілі, можна виокремити специфічні особливості культури локальної демократії групових суб'єктів, що залежать від міцності соціальних зв'язків мешканців об'єднаних місцем проживання, усвідомлення ними необхідності участі у вирішенні спільних проблем та визначити рівні даних суб'єктів.

Першим (базовим) рівнем можна вважати найменшу частину територіальної громади, в межах якої можуть реалізовуватись механізми локальної демократії, яка характеризується: спільним проживанням на невеликій території (багатоквартирний будинок, вулиця або квартал (чи їх частина) на території індивідуальної забудови); найтіснішими соціальними зв'язками всередині групи (зокрема, велика кількість мешканців може бути особисто знайома та об'єднана спіль- 
ними інтересами тощо); обізнаність більшості мешканців 3 проблемами території проживання та можливість ефективної безпосередньої комунікації між ними 3 метою подолання даних проблем; невелика кількість мешканців (не більше двох тисяч осіб).

Другим (основним) рівнем є частина територіальної громади, об'єднана спільним проживанням на території однієї або кількох вулиць, кварталів. Для цього рівня характерні слабші соціальні зв'язки всередині групи, менша обізнаність із місцевими проблемами (у зв'язку 3 їх диференціацією та наявністю як загальних проблем, актуальних для всіх мешканців, так i проблем, актуальних для окремих сегментів всередині території) та менша, порівняно з базовим рівнем, можливість комунікації та мобілізації для їх подолання, кількість мешканців - в межах п’яти тисяч осіб.

На базовому та основному рівні можлива реалізація механізмів локальної демократії, що потребує участі більшості мешканців даної території, хоча, починаючи $з$ другого рівня, можна спостерігати прояви представницької демократії: проведення загальних зборів у вигляді конференції тощо.

Третій (загальний рівень) - здійснення механізмів локальної демократії на рівні мікрорайону, району у місті або територіальної громади в цілому. Характеризується слабкістю або відсутністю соціальних зв'язків внаслідок великої території або кількості населення. На загальному рівні громаду зазвичай репрезентують найбільш активні, мотивовані на вирішення спільних проблем населеного пункту мешканці, які ініціюють та беруть участь у громадських слуханнях, громадських ініціативах тощо.

Також слід зазначити, що в окремих випад- ках територіальна громада невеликих населених пунктів, як суб'єкт культури локальної демократії в цілому, за вищезазначеними критеріями може відповідати базовому (сільська громада) або основному (відносно великі сільські громади, громади невеликих селищ міського типу тощо).

\section{Висновки.}

Таким чином, громада є суб'єктом культури локальної демократії як особливої, специфічної сфери (частини) локальної політичної культури, системи знань, цінностей, переконань членів територіальної громади стосовно законодавчо визначених механізмів локальної демократії (громадських слухань, зборів громадян за місцем проживання, діяльності органів самоорганізації населення, місцевих референдумів), а також форми політичної участі у згаданих механізмах, зразків поведінки, соціальних норм, фундаментальних принципів i суспільних інститутів, що орієнтують суб' єктів на ті чи інші форми активності у політиці, забезпечують передачу накопиченого досвіду, сприяють стійкості локальної демократії в часі.

Поняття культури локальної демократії передає, насамперед, рівень усвідомлення громадянином громадських завдань, його практичної активності у справі втілення їх в життя. У цьому сенсі вона є структурним елементом громадянського життя і виявом ступеню зрілості суспільства, здатності забезпечення загальногромадянських інтересів, форм і механізмів вироблення і реалізації спільних рішень, узгоджених дій.

Специфічні особливості культури локальної демократії виявляються на трьох рівнях групових суб'єктів (базовий, основний, загальний), які виокремлені нами за критерієм міцності соціальних зв'язків мешканців, об'єднаних місцем проживання, усвідомлення ними необхідності участі у вирішенні спільних проблем.

\section{БІБІЛІОГРАФІЧНІ ПОСИЛАННЯ}

1. Конституція України // Відомості Верховної Ради України. - 1996. - № 30. - Ст. 141.

2. Про місцеве самоврядування в Україні: Закон України від 21 травня 1997 р. // Відомості Верховної Ради України - 1997. - № 24. - Ст. 170.

3. Про органи самоорганізації населення: Закон України від 11 липня 2001 року № 2625-III // Відомості Верховної Ради України. - 2001. - № 48. - Ст. 254.

4. Баймуратов М. А. Муниципальная власть: актуальные проблемы становления и развития в Украине / М. А. Баймуратов, В. А. Григорьев. - Одеса: Юридична література, 2003. - 896 с.

5. Батанов О. І. Конституційно-правовий статус територіальних громад в Україні / О. І. Батанов. - Київ: Вид. дім «Київ», 2003. -512 с.

6. Бітем Д. Головні принципи й показники демократичного аудиту / Д. Бітем // Визначення і вимірювання демократії. - Львів: Літопис, 2005. - С. 42-67.

7. Була С. П. Теоретико-методологічний аналіз локальної демократії як умови та інструменту становлення консолідованої демократії в перехідних суспільствах (на прикладі України): дис. ... канд. політ. наук: 23.00.01 / С. П. Була; Львівський національний університет імені Івана Франка. - Львів, 2012. - 233 с.

8. Задорожний О. Європейська хартія місцевого самоврядування / О. Задорожний // Політична енциклопедія. Київ: Парламентське видавництво, 2011. -808 с.

9. Королько В. Г. Основы паблик рилейшнз / В. Г. Королько. - М.: «Рефл-бук», Киев: «Ваклер», 2000. - 528 с. 10. Лендьєл М. Теоретико-методологічні засади аналізу локальної політичної культури / М. Лендьєл // Політич- 
ний менеджмент. - 2008. - № 5. - С. 11-22.

11. Місцева демократія в Україні: нові стандарти / М. В. Лациба, І. М. Лукеря, О. Л. Ващук-Огданська. - Київ: Агентство «Україна», 2013. - 236 с.

12. Місцеве самоврядування в Україні: проблеми та перспективи / За ред. В. М. Безчастного. - Донецьк: Донецький юрид. інститут при Донецькому національному університеті, 2005. - 272 с.

13. Муніципальне право України: підручник / За ред. В. Ф. Погорілка, О. Ф. Фрицького. - Київ: Юрінком Інтер, 2006. -592 c.

14. Орзіх М. Концепція правового статусу самоврядних територій і органів місцевого самоврядування / М. Орзіх // Місцеве та регіональне самоврядування в Україні. - 1995. - № 1. - С. 67-75.

15. Панченко Т. В. Регіональна і локальна ідентичності як складові культури субсидіарної демократії / Т. В. Панченко // Науковий часопис Національного педагогічного університету імені М. П. Драгоманова. Серія № 22. Політичні науки та методика викладання соціально-політичних дисциплін. - Київ: Вид-во НПУ імені М.П. Драгоманова, 2010. - № 4. - С. 72-77.

16. Свідзинський А. Самоорганізація і культура / А. Свідзинський. - Київ: Вид-во ім Олени Теліги, 1999. - 288 с. 17. Слиз А. Локальная и региональная идентичность в процессе глобализации / А. Слиз, М. Щепанський // Вісник СевДТУ. Вип. 94: Філософія: зб. наук. пр. - Севастополь: Вид-во СевНТУ, 2009. - С. 3-7.

18. Стан локальної демократії в містах України: роль громад та органів місцевого самоврядування. Аналітичний звіт за підсумками виконання проекту «Моніторинг діяльності органів місцевого самоврядування у сфері розвитку локальної демократії» / За ред. В. І. Брудного, А. С. Крупника, О. С. Орловського. - Одеса: ХОББІТ ПЛЮС, 2008. - 168 c.

19. Business Dictionary. - Retrieved from: http://www.businessdictionary.com/definition/community.html.

\section{REFERENCES}

1. Konstytucija Ukrajiny [The Constitution of Ukraine]. (1996). Vidomosti Verkhovnoji Rady Ukrajiny, 30 , art. 141 [in Ukrainian].

2. Pro misceve samovrjaduvannja v Ukrajini: Zakon Ukrajiny vid 21 travnja 1997 [On Local Self-Government in Ukraine: Law of Ukraine dated May 21, 1997]. (1997). Vidomosti Verkhovnoji Rady Ukrajiny, 24, art.170 [inUkrainian].

3. Pro orghany samoorghanizaciji naselennja: Zakon Ukrajiny vid 11 lypnja 2001 roku № 2625-III [On the bodies of selforganization of the population: Law of Ukraine dated July 11, 2001 № 2625-III]. (2001). Vidomosti Verkhovnoji Rady Ukrajiny, 48, art. 254 [in Ukrainian].

4. Baymuratov, M.A., \& Grigorev, V.A. (2003). Munitsipalnaya vlast: aktualnye problemy stanovleniya $i$ razvitiya $v$ Ukraine [Municipal authority: topical problems of formation and development in Ukraine]. Odesa: Yuridichna literatura [in Ukrainian].

5. Batanov, O. (2003). Konstytucijno-pravovyj status terytorialjnykh ghromad v Ukrajini [Constitutional and Legal Status of Territorial Communities in Ukraine]. Kyiv: Vyd. dim «Kyjiv» [inUkrainian].

6. Bitem, D. (2005). Gholovni pryncypy j pokaznyky demokratychnogho audytu. [Main Principles and Indicators of Democratic Audit]. Vyznachennja i vymirjuvannja demokratiji. Lviv: Litopys [in Ukrainian].

7. Bula, S.P. (2012). Teoretyko-metodologhichnyj analiz lokaljnoji demokratiji jak umovy ta instrumentu stanovlennja konsolidovanoji demokratiji v perekhidnykh suspiljstvakh (na prykladi Ukrajiny) [Theoretical and methodological analysis of local democracy as a condition and instrument for the formation of consolidated democracy in transitional societies (on the example of Ukraine)]. Candidate's thesis. Lviv: Ljvivsjkyj nacionaljnyj universytet imeni Ivana Franka [in Ukrainian].

8. Zadorozhnyj, O. (2011). Jevropejsjka khartija miscevogho samovrjaduvannja [European Charter of Local SelfGovernment]. Politychna encyklopedija. Kyiv: Parlamentsjke vydavnyctvo [in Ukrainian].

9. Korolko, V.G. (2000). Osnovy pablik rileyshnz [Basics of public relations]. Moscow: «Refl-buk», Kyiv: «Vakler» [in Russian].

10. Lendjjel, M. (2008). Teoretyko-metodologhichni zasady analizu lokaljnoji politychnoji kuljtury [Theoretical and Methodological Principles of Analysis of Local Political Culture]. Politychnyj menedzhment [in Ukrainian].

11. Lacyba, M.V., Lukerja, I.M., \& Vashhuk-Oghdansjka, O.L. (2013). Misceva demokratija v Ukrajini: novi standarty [Local democracy in Ukraine: new standards]. Kyiv: Aghentstvo «Ukrajina» [in Ukrainian].

12. Bezchastnogho, V.M. (2005). Misceve samovrjaduvannja v Ukrajini: problemy ta perspektyvy [Local Government in Ukraine: Problems and Prospects]. Donecjk: Donecjkyj juryd. instytut pry Donecjkomu nacionaljnomu universyteti [in Ukrainian].

13. Poghorilko, V.F., \& Frycjkogho, O.F. (2006). Municypaljne pravo Ukrajiny: Pidruchnyk [Municipal Law of Ukraine]. Kyiv: Jurinkom Inter [in Ukrainian].

14. Orzikh, M. (1995). Koncepcija pravovogho statusu samovrjadnykh terytorij i orghaniv miscevogho samovrjaduvannja [Concept of the Legal Status of Self-Governing Territories and Local Self-Government Bodies]. Misceve ta reghionaljne samovrjaduvannja $v$ Ukrajini [in Ukrainian].

15. Panchenko, T.V. (2010). Reghionaljna i lokaljna identychnosti jak skladovi kuljtury subsydiarnoji demokratiji [Regional and Local Identities as Components of the Culture of Subsidiary Democracy]. Naukovyj chasopys Nacionaljnogho pedaghoghichnogho universytetu imeni M. P. Draghomanova. Politychni nauky ta metodyka vykladannja socialjno- 
politychnykh dyscyplin № 4: Zbirnyk naukovykh pracj. Kyiv: Vyd-vo NPU imeni M.P. Draghomanova [in Ukrainian]. 16. Svidzynsjkyj, A. (1999). Samoorghanizacija i kuljtura [Self-organization and culture]. Kyiv: Vydavnyctvo imeni Oleny Telighy [in Ukrainian].

17. Slyz, A., \& Shhepansjkyj, M. (2009). Lokaljnaja y reghyonaljnaja ydentychnostj v processe ghlobalyzacyy [Local and regional identity in the process of globalization]. Visnyk SevDTU. Filosofija. Sevastopolj: Vyd-vo: SevNTU [in Russian] 18. Brudniy, V.I., Krupnyk, A.S., \& Orlovsjkiy O.S. (2008). Stan lokaljnoji demokratiji v mistakh Ukrajiny: rolj ghromad ta orghaniv miscevogho samovrjaduvannja. Analitychnyj zvit za pidsumkamy vykonannja proektu «Monitoryngh dijaljnosti orghaniv miscevogho samovrjaduvannja u sferi rozvytku lokaljnoji demokratiji» [The Status of Local Democracy in Ukrainian Cities: The Role of Communities and Local Self-Government Bodies. Analytical report on the results of the implementation of the project «Monitoring the activities of local self-government in the field of local democracy»]. Odesa: HOBBIT PLUS [in Ukrainian].

19. Business Dictionary [Business Dictionary]. Retrieved from: http:/www.businessdictionary.com/definition/ community.html.

\section{Цумарев Марат Іванович}

Заступник директора

Центральноукраїнський інститут Приватного акціонерного товариства «Вищий навчальний заклад «Міжрегіональна Академія управління персоналом»

25000, Кропивницький, вул. Варшавська 2

\section{Tsumariev Marat}

Deputy Director

Central Ukrainian Institute under Private Joined-Stock Company «Private Higher Educational Institution «Interregional Academy of Personnel Management».

2, Varshavska Str., Kropyvnytskyi, 25005, Ukraine

Email: zumar_ua@ukr.net

Цитування: Цумарєв М. І. Громада як суб’єкт культури локальної демократії / М. І. Цумарєв // Науково-теоретичний альманах «Грані». - 2018. - Т. 21. - № 3. - С. 82-89.

Citation: Tsumariev, M.I. (2018). Hromada yak subiekt kultury lokalnoi demokratii [Community as a subject of local democracy culture]. Scientific and theoretical almanac «Grani», 21(3), 82-89. 